\title{
Design strategies and measures to minimise operation energy use for passive houses under different climate scenarios
}

\author{
Uniben Yao Ayikoe Tettey • Ambrose Dodoo • \\ Leif Gustavsson
}

Received: 21 October 2017 / Accepted: 15 July 2018 /Published online: 14 August 2018

(C) The Author(s) 2018

\begin{abstract}
Here, the implications of different design strategies and measures in minimising the heating and cooling demands of a multi-storey residential building, designed to the passive house criteria in Southern Sweden are analysed under different climate change scenarios. The analyses are conducted for recent (1996-2005) and future climate periods of 2050-2059 and 2090-2099 based on the Representative Concentration Pathway scenarios, downscaled to conditions in Southern Sweden. The considered design strategies and measures encompass efficient household equipment and technical installations, bypass of ventilation heat recovery unit, solar shading of windows, window size and properties, building orientation and mechanical cooling. Results show that space heating demand reduces, while cooling demand as well as risk of overheating increases under future climate scenarios. The most important design strategies and measures are efficient household equipment and technical installations, solar shading, bypass of ventilation heat recovery unit and window $U$-values and $g$-values. Total annual final energy demand decreased by $40-51 \%$, and overheating is avoided or significantly reduced under the considered climate scenarios when all the strategies are implemented. Overall, the total annual primary energy use for operation decreased by $42-54 \%$. This study emphasises the importance of considering different design strategies and measures in minimising the operation
\end{abstract}

U. Y. A. Tettey $(\bowtie) \cdot$ A. Dodoo $\cdot$ L. Gustavsson Sustainable Built Environment Research Group, Faculty of Technology, Linnaeus University, SE-35195 Växjö, Sweden e-mail: uniben.tettey@lnu.se energy use and potential risks of overheating in lowenergy residential buildings under future climates.

Keywords Climate change $\cdot$ Passive houses . Overheating $\cdot$ Heating and cooling demand $\cdot$ Primary energy $\cdot$ Design strategies

\section{Introduction}

Greenhouse gases (GHGs) concentration in the atmosphere has increased to significant levels since the preindustrial era (IPCC Intergovermental Panel on Climate Change 2013). Global GHG emissions nearly doubled in 2010 compared to 1970 (IPCC Intergovernmental Panel on Climate Change 2014c). Similarly, GHG emissions from the building sector more than doubled over the same period, accounting for $19 \%$ of all global GHG emissions (IEA 2012). Energy-related $\mathrm{CO}_{2}$ emissions represent the largest share of global GHG emissions, accounting for about $60 \%$ (IEA International Energy Agency 2015). GHGs emissions are mainly due to human activities and affect the earth's balance of radiative energy, increasing the mean surface temperature and causing a wide range of impacts on the global climate system. Average temperature over the European (EU) land area for the decade $2002-2011$ is $1.3{ }^{\circ} \mathrm{C}$ higher than that for 1850-1899 (IPCC Intergovernmental Panel on Climate Change 2014a). In Sweden, different climate scenarios show predictions of an annual average temperature rise of $2-6^{\circ} \mathrm{C}$ for 2100 , compared to the average for 1961-1990 with the biggest changes expected to 
occur in winter (SMHI Swedish Meteorological and Hydrological Institute 2015). Climate change may influence buildings' energy use and therefore building design strategies must include effective mitigation and adaptation measures to address its impacts.

The production, operation and end-of-life activities of buildings are associated with large energy use and present many climatic and environmental challenges. Residential and service buildings account for about $38 \%$ of the total final energy use in the EU (Eurostat 2016) and in Sweden (Swedish Energy Agency 2016). A large part of the final operation energy use of the residential building stock in many EU countries is attributable to space heating (Saheb et al. 2015). However, under climate change, these patterns of energy use may change, affecting buildings' indoor environment and comfort levels, especially in highly energy efficient buildings. Several performance evaluations of lowenergy buildings under different climate contexts suggest high cooling demands and overheating risks (Badescu et al. 2010; Mlakar and Štrancar 2011; Rohdin et al. 2014; Tabatabaei Sameni et al. 2015). Studies that have explored the impact of climate change on the heating and cooling demands of buildings in different climate contexts show trends of decreasing heating and increasing cooling demands under climate change (Berger et al. 2014; Dodoo and Gustavsson 2016; Wang and Chen 2014). Some studies have analysed the implications of different building design strategies in the context of climate change. (Holmes and Hacker 2007) analysed different ventilation design strategies for different building types in the United Kingdom (UK) considering climate change. They found that high thermal mass and a mixed-mode ventilation strategy give reduced energy use and comfortable indoor climate. Gaterell and McEvoy 2005 analysed different energy efficiency measures for a typical old residential building in the UK under climate change. The considered measures were roof insulation, heavy curtain or insulated shutters, double glazing and cavity wall insulation. Their results showed that double glazing gave the highest space heating savings and the lowest space cooling demand, compared to the initial single-glazed windows. (Karimpour et al. 2015) explored climate change effects on different design options to achieve energy efficient envelopes for buildings in Australia. They considered different window glazing, floor covering, wall and roof insulation thicknesses, reflective roofs and foil under current and future climates. They observed that cooling demand becomes more important in highly insulated buildings. Thermal performance analysis of buildings for future climates are mostly based on the Special Report on Emissions Scenarios, with only a few studies (e.g. (Dodoo and Gustavsson 2016)) based on the recently published Representative Concentration Pathways (RCPs) scenarios by (IPCC Intergovernmental Panel on Climate Change 2014b).

New buildings present many possibilities to adopt design strategies to fit local climate conditions in order to optimise both heating and cooling demands, especially under climate change. In this study, we explore the influence of climate change on the annual energy use of a version of a multi-storey residential building in Sweden, considering different design strategies with the aim to minimise the space heating and cooling demands. The studied building version is modelled to meet the requirements of the Swedish passive house criteria (FEBY 12 2012). The considered strategies and measurses include energy-efficient appliances and building technical installations, solar shading of windows, bypass of the ventilation heat recovery unit to control cooling, different combinations of window thermal transmittance ( $U$-values) and solar transmittance ( $g$ values), different façade orientations and share of window areas as well as mechanical cooling. The analysis is based on dynamic hour-by-hour energy balance calculations of the building version with and without the considered design strategies and under different climate scenarios to explore the impact of climate change on the building's thermal performance. Variations in outdoor temperature, solar radiation, wind speed and relative humidity are considered for the analysed climate scenarios. Further, a system analysis approach is employed to assess the effect of the implemented design strategies on the primary energy use of the building version, taking into account the complete energy supply chain. Unlike simplified set of primary energy factors, this approach involves detailed analysis of the various activities and processes along the energy chains of the different energy supply systems, including extraction, refining and conversion of natural resources, transport, conversion to heat and electricity and distribution for final use.

\section{Building description}

This study is based on a recently completed multi-storey residential building in Växjö, Southern Sweden. The 
building is 6-storey high in prefab concrete frame and comprises 24 apartment units of 1-3 bedrooms with a total heated floor area of $1686 \mathrm{~m}^{2}$. The foundation consists of $100 \mathrm{~mm}$ concrete slab on 300 and $200 \mathrm{~mm}$ layers of expanded polystyrene insulation and crushed stone, respectively. The external walls consist of $100 \mathrm{~mm}$ expanded polystyrene insulation sandwiched between 100 and $230 \mathrm{~mm}$ concrete panels on the outside and inside respectively. The intermediate floors are $250 \mathrm{~mm}$ concrete slabs and the ceiling floor consists of $250 \mathrm{~mm}$ concrete slab and $500 \mathrm{~mm}$ mineral wool insulation with wooden trusses and a roof covering over layers of asphalt-impregnated felt and plywood. The windows and external doors have clear glass doubleglazed panels with wood frames, which are clad with aluminium profiles on the outside. The window and door $U$ value and $g$ value of the studied building are $1.2 \mathrm{~W} / \mathrm{m}^{2} \mathrm{~K}$ and 0.6 , respectively. The west façade has the largest window area of about $161.2 \mathrm{~m}^{2}$, followed by the east façade with a total window area of $74.5 \mathrm{~m}^{2}$. The north and south façades have the same share of window areas of $39.3 \mathrm{~m}^{2}$ each. The building has balanced ventilation with a heat recovery system. For this analysis, changes are modelled to the envelope characteristics of the building to meet the energy standard of the Swedish passive house criteria (FEBY 12 2012). Figure 1 shows a typical floor plan, section and photograph of the building. The thermal properties of the analysed building according to the Swedish passive house criteria are given in Table 1.

\section{Method}

The analysis is based on dynamic hour by hour energy balance simulation of the building version for recent and projected future climate conditions, including modelling different design strategies and using a system analysis approach to explore climate change implications on the final and primary energy use.

\section{Reference and future climate scenarios}

The energy performance of the building version was modelled for average climate data of 1996-2005 as the reference climate period, and for climate scenarios under 2050-2059 and 2090-2099, depicting mid-century (2050s) and end of century (2090s) future climate periods, respectively. The period 1996-2005 is suggested to be more representative of current climate conditions compared to 1961-1990 due to climate change (Remund et al. 2010; SMHI (Swedish Meteorological and Hydrological Institute) 2013). Future climate data based on global climate model (GCM) of the HadGEM2 Earth system for the county of Kronoberg, where the city of Växjö is situated, were obtained from the regional climate model (RCA4) administered by the Rossby Centre of the Swedish Meteorological and Hydrological Institute (SMHI Swedish Meteorological and Hydrological Institute 2011). The climate data from the RCA4 model are based on monthly resolutions and to obtain hourly resolution datasets for the future climate periods, they were downscaled using the morphing approach (Belcher et al. 2005) with 1961-1990 as the baseline period. The morphing approach is considered reliable for generating future climate datasets in line with current best projections for thermal simulation for real buildings (Belcher et al. 2005) and has been applied in several studies (Dodoo and Gustavsson 2016; RubioBellido et al. 2016). The considered future climate scenarios are based on the Representative Concentration Pathways (RCPs) (IPCC Intergovernmental Panel on Climate Change 2014b). The RCPs consist of one mitigation scenario leading to very low radiative forcing level (RCP2.6), two stabilisation scenarios (RCP4.5 and RCP6.0), and one scenario with very high GHG emissions (RCP8.5), each characterised by atmospheric concentration of $\mathrm{CO}_{2}$ equivalent of $450,650,850$ and 1370 ppm by 2100 , respectively (IPCC Intergovermental Panel on Climate Change 2013; IPCC Intergovernmental Panel on Climate Change 2014b). The analyses in this study are based on RCPs 2.6, 4.5 and 8.5 climate scenarios and take into account variations in outdoor temperature, solar radiation, wind speed and relative humidity. RCPs 4.5 and 8.5 characterise low and high radiative forcing levels, respectively, and are suggested to reflect the contrast between currently feasible and business-as-usual climate change mitigation goals (Mora et al. 2013). RCP2.6 portrays ambitious climate change mitigation goals and is increasingly suggested to be unfeasible (Mora et al. 2013). However, the Conference of Parties (COP21) reached a consensus to limit global temperature rise below $2{ }^{\circ} \mathrm{C}$, above pre-industrial levels by 2100 (UNFCCC United Nations Framework Convention on Climate Change 2015). The $2{ }^{\circ} \mathrm{C}$ global temperature target is suggested to be achievable through a rapid transition to climate change mitigation goals similar to 

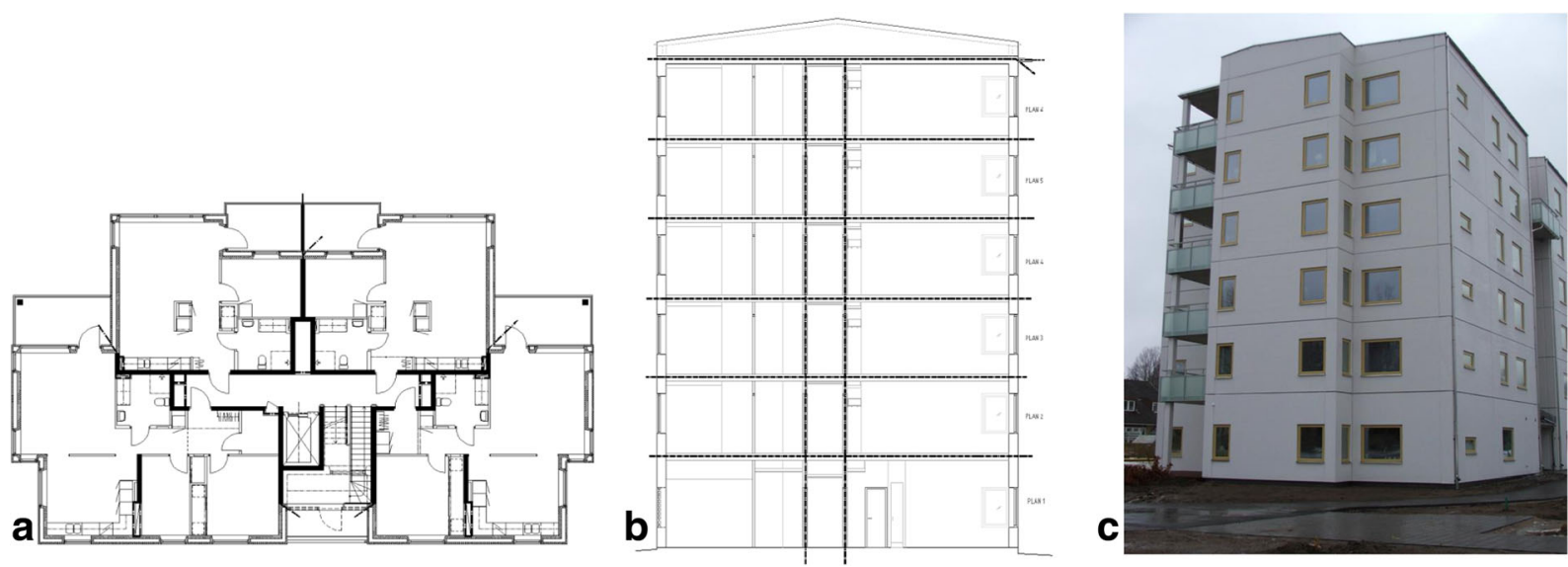

Fig. 1 Typical floor plan (a), section (b) and photograph (c) of the studied building

the RCP2.6 pathway (Sanford et al. 2014). Monthly average variations as well as the minimum and maximum values for outdoor temperature, solar radiation, wind speed and relative humidity for the considered climate scenarios are shown in Table 2.

Final energy calculations

The VIP+ energy simulation software (StruSoft 2012) was used to perform dynamic hour-by-hour energy balance calculations of the building version under the different climate scenarios before and after implementing the considered design strategies. The final energy calculations include space heating and cooling, tap water heating and electricity for ventilation and household equipment and lighting. The annual hourly indoor air temperature profiles were also modelled with the VIP+ software and the percentage of annual operating hours that the cooling set point and overheating temperature threshold of $28{ }^{\circ} \mathrm{C}$ based on (CIBSE 2006) are exceeded, were calculated. The VIP+ energy simulation software performs detailed multi-zone and multidimensional modelling of thermal bridges and heat storage capacity of building envelope components, taking into account the interactions between building design, geometry, thermal characteristics of building envelope elements and climate conditions as well as HVAC and other technical installation for different building occupancy and operational schedules. The software is validated by the International Energy Agency's BESTEST, ANSI/ASHRAE Standard 140 and CEN 15265, and it is widely used by building industry consultants and engineers in the Nordic region as well as in several scientific studies (Burke et al. 2017; Noris et al. 2014; Siggelsten 2014). The Swedish National Board of Housing, Building and Planning in a cost analysis report on building energy efficiency improvement noted that the VIP+ energy simulation software generally gives good and consistent results in comparison with other considered software (Boverket 2013). The analysis was done with the climate data for the city of Växjö (latitude $56^{\circ} 52^{\prime} \mathrm{N}$, longitude $14^{\circ} 48^{\prime} \mathrm{E}$ ), where the building is located. Key input parameter values and assumptions for the energy balance calculations are presented in Table 3.

\section{Design strategies and measures}

The planning and construction of new buildings present a wide range of possibilities to optimise their designs to adapt them to the local climate and to use different technologies to minimise energy use. Several design

Table 1 Thermal properties of the building version to the Swedish passive house criteria

\begin{tabular}{|c|c|c|c|c|c|c|c|}
\hline \multirow[t]{2}{*}{ Description } & \multicolumn{5}{|c|}{$U$-value $\left(\mathrm{W} / \mathrm{m}^{2} \mathrm{~K}\right)$} & \multirow{2}{*}{$\begin{array}{l}\text { Air leakage at } \\
50 \mathrm{~Pa}\left(1 / \mathrm{s} \mathrm{m}^{2}\right)\end{array}$} & \multirow[t]{2}{*}{ Mechanical ventilation } \\
\hline & Ground floor & External walls & Windows & Doors & Roof & & \\
\hline Passive house criteria & 0.11 & 0.11 & 0.80 & 0.80 & 0.05 & 0.3 & Balanced with heat recovery \\
\hline
\end{tabular}


Table 2 Variations in the climate characteristics of the considered RCP climate scenarios

\begin{tabular}{|c|c|c|c|c|c|c|c|}
\hline & $\begin{array}{l}\text { Reference } \\
1996-2005\end{array}$ & $\begin{array}{l}2050 \mathrm{~s} \\
\text { RCP2.6 }\end{array}$ & $\mathrm{RCP} 4.5$ & RCP8.5 & $\begin{array}{l}\text { 2090s } \\
\text { RCP2.6 }\end{array}$ & $\mathrm{RCP} 4.5$ & RCP8.5 \\
\hline \multicolumn{8}{|c|}{ Outdoor temperature, ${ }^{\circ} \mathrm{C}$} \\
\hline Minimum & -17 & -14 & -14 & -13 & -14 & -13 & -12 \\
\hline Average & 7 & 8 & 9 & 10 & 8 & 10 & 12 \\
\hline Maximum & 28 & 29 & 29 & 28 & 28 & 31 & 33 \\
\hline \multicolumn{8}{|c|}{ Solar radiation, $\mathrm{W} / \mathrm{m}^{2}$} \\
\hline Minimum & 0 & 0 & 0 & 0 & 0 & 0 & 0 \\
\hline Average & 105 & 101 & 103 & 103 & 100 & 105 & 104 \\
\hline Maximum & 987 & 892 & 883 & 874 & 834 & 902 & 910 \\
\hline \multicolumn{8}{|c|}{ Wind speed, $\mathrm{m} / \mathrm{s}$} \\
\hline Minimum & 0 & 0 & 0 & 0 & 0 & 0 & 0 \\
\hline Average & 3 & 4 & 4 & 4 & 4 & 4 & 4 \\
\hline Maximum & 14 & 14 & 14 & 14 & 14 & 14 & 14 \\
\hline \multicolumn{8}{|c|}{ Relative humidity, $\%$} \\
\hline Minimum & 33 & 0 & 0 & 0 & 0 & 0 & 0 \\
\hline Average & 81 & 86 & 86 & 86 & 86 & 86 & 86 \\
\hline Maximum & 100 & 105 & 103 & 103 & 104 & 102 & 102 \\
\hline
\end{tabular}

strategies and measures may be applicable but in this study, the focus is on passive strategies based on optimised design of the building façade elements and the use of efficient appliances and technical installations to minimise the operation energy demand of the analysed building. The thermal performance of the building version before and after the implemented design strategies is analysed and compared under different climate scenarios. The considered strategies and measures are implemented cumulatively in the following order based on simplified assumptions and ease of implementation:

- Efficient household equipment and technical installations based on best available technology (BAT)

The household equipment and technical installations in the initial building version are assumed to be of today's standard technology. These are changed to efficient household equipment and technical installations based on best available technology (BAT). Values for the key input parameters and assumptions for household equipment and technical installations based on BAT are given in Table 4. The heat gains from electrical appliances, lighting and persons are modelled, taking into account seasonal and daily variations based on average profiles for the Swedish context (Liu et al. 2015; Lundström and Wallin 2016).
- By-passing the ventilation heat recovery (VHR) unit when the cooling set point is exceeded.

- Solar shading of windows to be activated when the cooling set point is exceeded.

- Different combinations of window thermal $(U$ values) and solar ( $g$-values) transmittances. The window $U$-value requirement according to the Swedish passive house criteria is $0.8 \mathrm{~W} / \mathrm{m}^{2} \mathrm{~K}$ (FEBY 12 2012) and in this study, window $U$-value of $0.6 \mathrm{~W} / \mathrm{m}^{2} \mathrm{~K}$ with $\mathrm{g}$-value ranges of $0.2-0.6$ are also considered based on reported commercially available and potential future window technologies (Baetens et al. 2010; Cuce and Riffat 2015; Hammarberg and Roos 2003; Minne et al. 2015).

- Decreasing or increasing the proportion of window areas on different façades by 20 and $40 \%$.

- Different façade orientations to optimise space heating and cooling demand.

- Mechanical cooling with air conditioners to meet remaining cooling demand after the implemented design strategies.

\section{Primary energy calculations}

The ENSYST program was used to calculate the primary energy use, required to provide the final energy for 
Table 3 Key input parameters and assumptions for energy balance modelling of initial building (before implemented strategies)

\begin{tabular}{|c|c|c|c|}
\hline Description & Parameter & Values/assumptions & Remarks \\
\hline \multirow{2}{*}{$\begin{array}{l}\text { Indoor temperature } \\
\text { set points }\end{array}$} & Heating & $21{ }^{\circ} \mathrm{C} / 18{ }^{\circ} \mathrm{C}$ & Living area/common area \\
\hline & Cooling & $27^{\circ} \mathrm{C}$ & Estimated \\
\hline \multirow[t]{3}{*}{ Heat gains } & Persons & $80 \mathrm{~W} /$ person & $\begin{array}{l}\text { Average value based on (SVEBY 2013) with variable annual } \\
\text { profile considered in simulation }\end{array}$ \\
\hline & Lighting and appliance & $2.94 \mathrm{~W} / \mathrm{m}^{2}$ & $\begin{array}{l}\text { Standard equipment. Average values estimated based on data } \\
\text { from (de Almeida et al. 2008) with annual variations } \\
\text { considered in simulation }\end{array}$ \\
\hline & Hot water circulation & $1.05 \mathrm{~W} / \mathrm{m}^{2}$ & $\begin{array}{l}\text { Standard equipment. Average values estimated based on } \\
\text { (Isover 2016) with annual variations considered in simulation }\end{array}$ \\
\hline Hot water & Annual average intensity & $2.85 \mathrm{~W} / \mathrm{m}^{2}$ & $\begin{array}{l}\text { Standard taps and shower heads. Average value based on } \\
\text { (SVEBY 2013) with annual variations considered in simulation }\end{array}$ \\
\hline Electric power use & Annual average intensity & $3.41 \mathrm{~W} / \mathrm{m}^{2}$ & $\begin{array}{l}\text { Standard electric equipment and lighting. Estimated based on } \\
\text { data from (de Almeida et al. 2008) }\end{array}$ \\
\hline \multirow{4}{*}{$\begin{array}{l}\text { Ventilation, pumps, } \\
\text { heat exchanger } \\
\text { and fans }\end{array}$} & Air change rate ${ }^{a}$ & $0.1 / 0.35 \mathrm{l} / \mathrm{s} \mathrm{m}^{2}$ & Based on (BBR Boverkets Byggregler 2015) \\
\hline & Heat recovery & $76 \%$ & Based on (Swedish Energy Agency 2010) \\
\hline & Fan pressure & $400 \mathrm{~Pa}$ & Estimated based on (StruSoft 2012) \\
\hline & Fan efficiency & $33 \%$ & Based on (Brelih 2012) \\
\hline
\end{tabular}

${ }^{a}$ Air change rate of 0.1 and $0.351 / \mathrm{sm}^{2}$ are considered when the building is assumed to be unoccupied and occupied, respectively, based on Swedish building code (BBR Boverkets Byggregler 2015)

space and tap water heating and electricity for space cooling, ventilation as well as household equipment and lighting for the building version before and after the implemented strategies and measures. ENSYST calculates primary energy use, taking into account the complete energy chains of the different energy supply systems from natural resources extracted, transported and refined to produce the supplied final energy to the building. Typically, multi-storey apartment buildings are heated with district heating in Sweden (Swedish Energy Agency 2015b). The building is assumed to be heated with a biomass-based district heating system, comprising a combined heat and power (CHP) plant using wood chips, and heat-only boilers (HOB) using wood chips or wood powder producing $68,30.5$ and $1.5 \%$, respectively, of the total district heat production. A CHP plant cogenerates heat and electricity and therefore allocation issues may arise. The cogenerated electricity from the CHP plant is assumed to replace electricity from a stand-alone plant with similar fuel and technology as the CHP plant based on the substitution method to avoid co-product allocation (Gustavsson and Karlsson 2006). The primary energy use for the replaced electricity in the stand-alone plant is thus subtracted from that of the CHP plant to obtain the primary energy for the heat. An alternative heat supply based on biomass-fired heat-only boilers (HOB) is also considered to assess the primary energy implications of different supply systems. The electricity for the air conditioners, ventilation and household equipment is assumed to be covered by a stand-alone biomass-based steam turbine (BST) plant. In Sweden, efforts are being made to increase the renewable share of electricity generation. While electricity generation from wind power has more than doubled over the last decade, the contribution from solar power still remains relatively small (Swedish Energy Agency 2015b). Assumption of solar electricity to supplement cooling demand for the building after implementing each successive design strategy is also considered in the primary energy analysis. The efficiencies and capacities of the considered energy supply systems used in the ENSYST program, to calculate the primary energy use, linked to the final heat and electricity use of the analysed building version are given in Table 5.

\section{Results}

Table 6 shows the annual final and primary energy demand for space heating and cooling, tap water heating and electricity for ventilation and household equipment 
Table 4 Key input parameters and assumptions for household equipment and technical installations based on best available technology (BAT)

\begin{tabular}{|c|c|c|c|}
\hline Description & Parameter & Values/assumptions & Remarks \\
\hline \multirow[t]{3}{*}{ Heat gains } & Lighting and appliance & $1.35 \mathrm{~W} / \mathrm{m}^{2}$ & $\begin{array}{l}\text { Efficient equipment. Average values with annual variations } \\
\text { considered in simulation. Estimated based on data from } \\
\text { (de Almeida et al. 2008). }\end{array}$ \\
\hline & Hot water circulation & $0.68 \mathrm{~W} / \mathrm{m}^{2}$ & $\begin{array}{l}\text { Efficient equipment. Average values with annual variations } \\
\text { considered in simulation. Estimated based on data } \\
\text { from (Isover 2016). }\end{array}$ \\
\hline & Sun & & Based on climate file. \\
\hline Hot water & Annual average intensity & $1.75 \mathrm{~W} / \mathrm{m}^{2}$ & $\begin{array}{l}\text { Efficient taps and shower heads based on } \\
\text { (Swedish Energy Agency 2015a). }\end{array}$ \\
\hline Electric power use & Annual average intensity & $1.69 \mathrm{~W} / \mathrm{m}^{2}$ & $\begin{array}{l}\text { Efficient electric equipment and lighting. Estimated based } \\
\text { on data from (de Almeida et al. 2008). }\end{array}$ \\
\hline \multirow{3}{*}{$\begin{array}{l}\text { Ventilation, pumps, } \\
\text { heat exchanger } \\
\text { and fans }\end{array}$} & Heat recovery & $80 \%$ & $\begin{array}{l}\text { Based on (Rohdin et al. 2014; Smeds and Wall 2007; } \\
\text { Swedish Energy Agency 2010) }\end{array}$ \\
\hline & Fan pressure & $200 \mathrm{~Pa}$ & Estimated \\
\hline & Fan efficiency & $50 \%$ & Based on (Camfil 2014). \\
\hline
\end{tabular}

of the initial building version (before implemented design strategies and measures) for the reference climate period of 1996-2005. Space and tap water heating are based on CHP, while electricity for space cooling, household equipment and ventilation is from a standalone BST plant. Electricity for household equipment and ventilation together form the largest share (43\%) of the operation energy demand, followed by tap water heating (24\%). The share of space heating and space cooling is similar, representing 16 and $17 \%$, respectively. Space heating and electricity for household equipment give the lowest and highest primary energy use, respectively.

Figure 2 illustrates the changes in space heating and cooling demands of the initial building version under the reference and future climate scenarios. Space heating demand decreases, while space cooling demand increases for the initial building version under the future climate scenarios. Space heating decreased by $14-31 \%$ while space cooling increased by $1-18 \%$ for midcentury (2050s) climate scenarios. For the end of century $(2090$ s) scenarios, space heating decreased by 14 $53 \%$ while space cooling increased by $30-59 \%$ except for RCP2.6, where cooling decreased by $1 \%$. Space cooling demand for the initial building version becomes more significant than space heating under the reference climate and the considered future climate scenarios with a cooling set point of $27{ }^{\circ} \mathrm{C}$ when no measures are implemented for cooling reduction. The variations in space heating and cooling demands for mid-century and end of century for RCPs 2.6 and 4.5 are small compared to that for RCP8.5.

The modelled annual hourly indoor air temperature profiles of the initial building version are shown in Fig. 3 for mid-century and end of century periods, compared to the reference climate. The profiles follow similar trends for all climate periods but are specifically higher under RCP8.5 for the end of century period. Indoor air temperatures exceeded the cooling set point by $43 \%$ of the total annual operating hours under the reference climate. The corresponding numbers are $45-$ $48 \%$ and $45-53 \%$ for mid-century and end of century

Table 5 Efficiencies and capacities of considered energy supply technologies based on (Truong et al. 2014)

\begin{tabular}{lll}
\hline Energy supply technology & Capacity & Efficiency \\
\hline Stand-alone power plant & $\left(\mathrm{MW}_{\text {elec }}\right)$ & $\left(\eta_{\text {elec }}\right)$ \\
Biomass steam turbine $(\mathrm{BST})$ & 400 & 0.40 \\
Cogeneration plants & $\left(\mathrm{MW}_{\text {heat }}\right)$ & $\left(\eta_{\text {eled }} / \eta_{\text {heat }}\right)$ \\
CHP-BST & 81 & $0.29 / 0.78$ \\
Heat-only boilers & $\left(\mathrm{MW}_{\text {heat }}\right)$ & $\left(\eta_{\text {heat }}\right)$ \\
Wood powder & 50 & 0.88 \\
Wood chip & 50 & 1.08 \\
End-use heating and cooling & & $(\eta)$ \\
District heating heat exchanger & & 0.95 \\
Room air conditioners & & 3 \\
\hline
\end{tabular}


Table 6 Annual final energy demand and primary energy use for the initial Passivhus 2012 building version under the reference climate (1996-2005) with space heating based on CHP

\begin{tabular}{llc}
\hline Description & $\begin{array}{l}\text { Annual final } \\
\text { energy demand } \\
\left(\mathrm{kWh} / \mathrm{m}^{2}\right)\end{array}$ & $\begin{array}{l}\text { Annual primary } \\
\text { energy use } \\
\left(\mathrm{kWh} / \mathrm{m}^{2}\right)\end{array}$ \\
\hline Space heating & 13.6 & 8.7 \\
Space cooling & 14.9 & 13.6 \\
Tap water heating & 21 & 13.4 \\
Ventilation electricity & 5.2 & 14.2 \\
Household electricity & 31.6 & 86.1 \\
Total & 86.4 & 136.1 \\
\hline
\end{tabular}

periods, respectively. Assuming an overheating temperature threshold of $28^{\circ} \mathrm{C}$ for not more than $1 \%$ of annual occupied time based on recommendations by CIBSE 2006, overheating occurs under all the considered climate scenarios for the initial building version. The proportion of hours that indoor air temperatures exceeded the overheating threshold was $40 \%$ of the total annual operating hours of the initial building version under the reference climate and between 41 and $44 \%$ and $41-51 \%$ under mid-century and end of century climate scenarios, respectively.

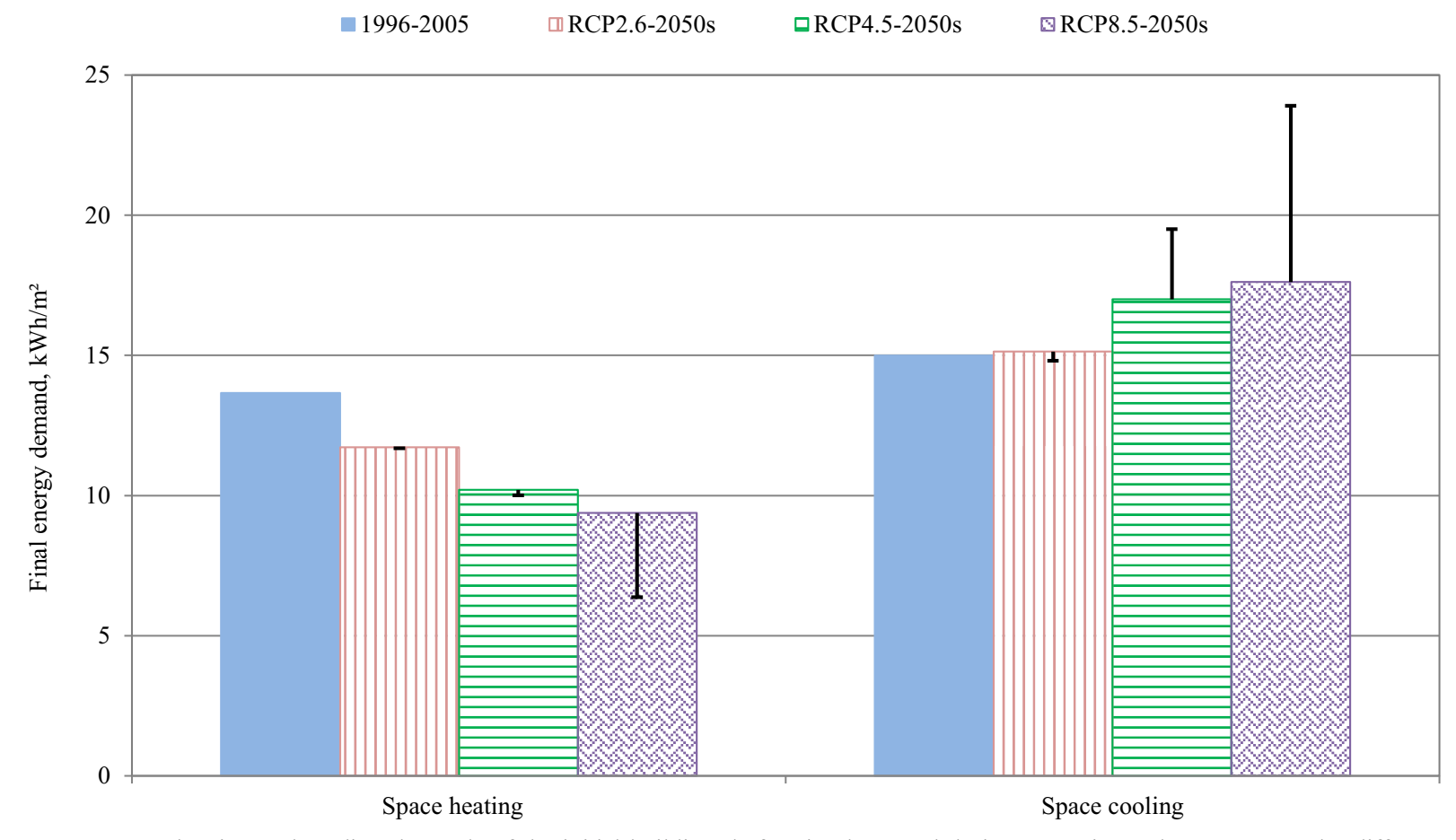

Fig. 2 Space heating and cooling demands of the initial building (before implemented design strategies and measures) under different climate scenarios. The main bars show mid-century (2050s), while the error bars show end of century (2090s) scenarios

The variations in space heating and cooling demands of the improved building version when the different design strategies are implemented cumulatively are shown in Fig. 4. The combination of $U$ - and $g$-values as well as the orientation and share of window areas are based on those resulting in the lowest total space heating and cooling demand for the building version under the different climate scenarios. Window $U$-value of $0.6 \mathrm{~W} /$ $\mathrm{m}^{2} / \mathrm{K}$ and $g$-value of 0.2 , north orientation of the largest window areas as well as reduced window areas by $40 \%$ consistently gave the lowest final space heating and cooling demands for the building version under the different climate scenarios. Space heating demand for the building version increased averagely by about $6 \mathrm{kWh} / \mathrm{m}^{2}(59 \%)$ under the considered climate scenarios, when all the strategies are implemented cumulatively. On the other hand, space cooling demand decreased by $17 \mathrm{kWh} / \mathrm{m}^{2}(98 \%)$. Overall, the total annual final energy demand decreased by $40 \%$ under the reference climate when all the strategies are implemented. The corresponding decreases are between 43 and $46 \%$ and $42-51 \%$ for mid-century and end of century climate scenarios, respectively.

The modelled annual hourly indoor temperature profiles of the building after the implemented strategies and

$$
\square \mathrm{RCP} 4.5-2050 \mathrm{~s} \quad \mathrm{RCP} 8.5-2050 \mathrm{~s}
$$




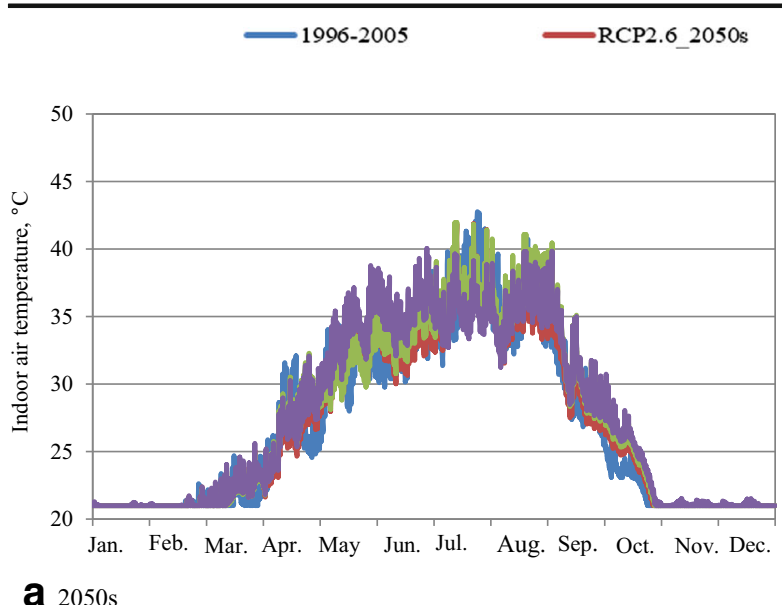

Fig. 3 Annual hourly indoor air temperature profiles for the initial building (before implemented design strategies and measures)

measures in Fig. 5 show that the proportion of hours exceeding the cooling set point is reduced from 47 to $4 \%$ of the total annual operating time under RCP 4.5 and from 53 to $17 \%$ under RCP 8.5 climate scenarios at end of century period. Overheating is avoided for the improved building version under all climate
RCP4.5-2050s

RCP8.5-2050s

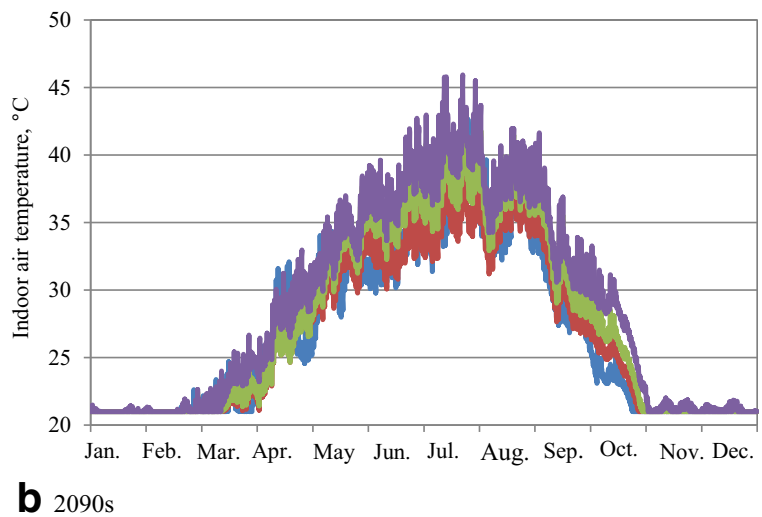

under different climate scenarios with no cooling measures implemented

scenarios, except RCP8.5-2090s climate scenario for which the proportion of hours that the overheating threshold is exceeded reduced significantly from 51 to $6 \%$. The proportion of hours that the overheating threshold is exceeded under the rest of the climate scenarios ranged between 0 and $0.1 \%$

$\boxminus \mathrm{RCP} 4.5-2050 \mathrm{~s} \quad \mathrm{RCP} 8.5-2050 \mathrm{~s}$

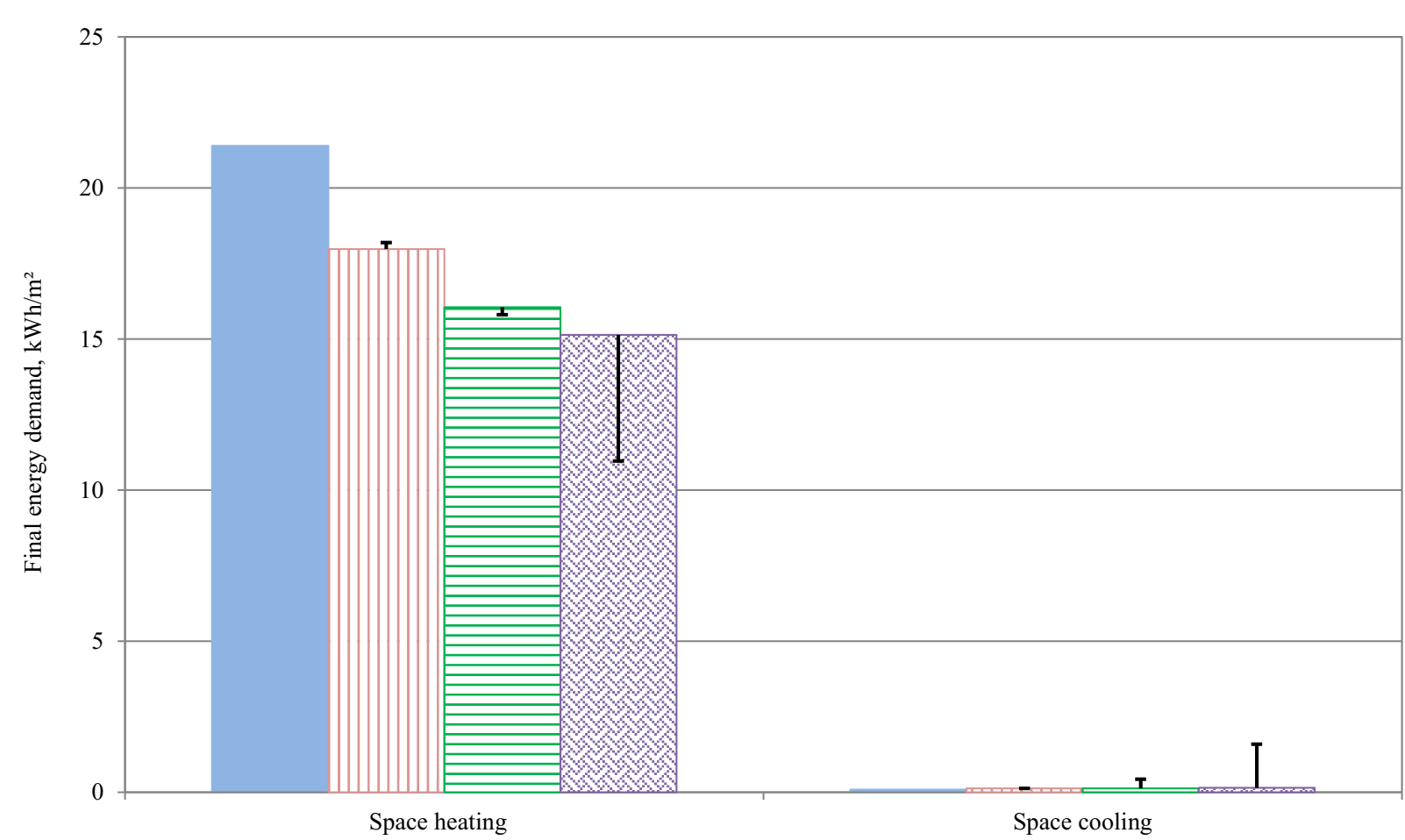

Fig. 4 Space heating and cooling demands of the improved building (after implemented design strategies and measures) under different climate scenarios. The main bars show mid-century (2050s), while the error bars show end of century (2090s) scenarios 

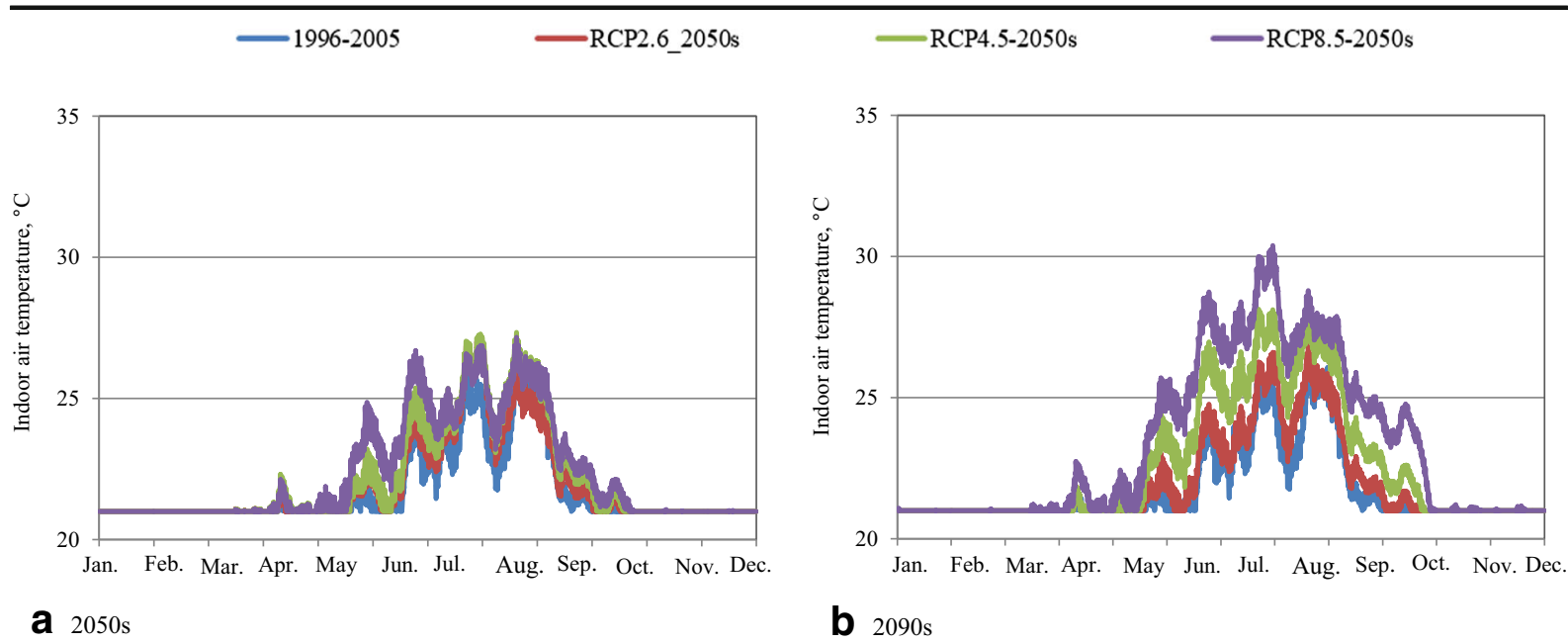

Fig. 5 Annual hourly indoor air temperature profiles for the improved building (after implemented design strategies and measures) under different climate scenarios

of the total annual operating hours, well below the $1 \%$ limit.

The total operation primary energy use for the initial building version and the improved version after the various design strategies and measures are implemented cumulatively under the different climate scenarios for space heating based on CHP and HOB is presented in

Table 7 Total annual primary energy use $\left(\mathrm{kWh} / \mathrm{m}^{2}\right)$ for operating the building before and after implementing different design strategies and measures cumulatively under different climate scenarios
Tables 7 and 8, respectively. The values in brackets show variations in primary energy use, when solar electricity is assumed to meet space cooling demand. The total primary energy use includes space heating, tap water heating and electricity for space cooling as well as for household equipment and ventilation. Air conditioners are assumed to meet the remaining cooling demand after

with space heating based on CHP. Numbers in brackets show when solar electricity is assumed for space cooling

\begin{tabular}{|c|c|c|c|c|}
\hline Description & $1996-2005$ & RCP2.6 & $\mathrm{RCP} 4.5$ & RCP8.5 \\
\hline \multicolumn{5}{|l|}{$2050 \mathrm{~s}$} \\
\hline Initial with standard technology & $136.1(128.0)$ & $135.0(126.8)$ & $135.7(126.5)$ & $135.7(126.2)$ \\
\hline$+\mathrm{BAT}$ & $79.0(73.8)$ & $77.4(72.3)$ & $77.8(71.8)$ & $77.6(71.4)$ \\
\hline + By-pass of VHR unit & $76.2(72.3)$ & $74.9(70.8)$ & $75.3(70.4)$ & $75.3(70.0)$ \\
\hline + Shading & $72.2(70.7)$ & $70.5(69.1)$ & $70.2(68.3)$ & $69.7(67.7)$ \\
\hline$+U$ - and $g$-values & $71.2(71.1)$ & $69.1(69.0)$ & $67.9(67.7)$ & $67.3(67.1)$ \\
\hline+ Orientation & $71.3(71.3)$ & $69.1(69.0)$ & $67.8(67.7)$ & $67.2(67.1)$ \\
\hline+ Window areas & $69.9(69.8)$ & $67.7(67.7)$ & $66.5(66.4)$ & $66.0(65.9)$ \\
\hline \multicolumn{5}{|l|}{2090 s } \\
\hline Initial with standard technology & $136.1(128.0)$ & $134.7(126.6)$ & $137.9(127.3)$ & $139.5(126.6)$ \\
\hline$+\mathrm{BAT}$ & $79.0(73.8)$ & $77.2(72.3)$ & $79.8(72.6)$ & $79.9(70.9)$ \\
\hline + By-pass of VHR unit & $76.2(72.3)$ & $74.8(70.8)$ & $77.6(71.2)$ & $78.1(69.7)$ \\
\hline + Shading & $72.2(70.7)$ & $70.5(69.1)$ & $71.3(68.7)$ & $70.8(66.7)$ \\
\hline$+U$ - and $g$-values & $71.2(71.1)$ & $69.2(69.1)$ & $68.3(67.8)$ & $66.3(65.0)$ \\
\hline+ Orientation & $71.3(71.3)$ & $69.2(69.2)$ & $68.1(67.7)$ & $65.9(64.9)$ \\
\hline+ Window areas & $69.9(69.8)$ & $67.9(67.8)$ & $66.6(66.4)$ & $64.6(63.7)$ \\
\hline
\end{tabular}


Table 8 Total annual primary energy use $\left(\mathrm{kWh} / \mathrm{m}^{2}\right)$ for operating the building before and after implementing different design strategies and measures cumulatively under different climate scenarios with space heating based on HOB. Numbers in brackets show when solar electricity is assumed for space cooling

\begin{tabular}{|c|c|c|c|c|}
\hline Description & 1996-2005 & $\mathrm{RCP} 2.6$ & $\mathrm{RCP} 4.5$ & RCP8.5 \\
\hline \multicolumn{5}{|l|}{$2050 \mathrm{~s}$} \\
\hline Initial with standard technology & $158.2(150.1)$ & $155.9(147.7)$ & $155.6(146.4)$ & $155.1(145.6)$ \\
\hline$+\mathrm{BAT}$ & $100.4(95.2)$ & $97.3(92.1)$ & $96.6(90.6)$ & $95.8(89.6)$ \\
\hline + By-pass of VHR unit & $97.8(93.9)$ & $94.8(90.7)$ & $94.2(89.3)$ & $93.5(88.2)$ \\
\hline + Shading & $93.8(92.3)$ & $90.5(89.0)$ & $89.1(87.2)$ & $87.9(86.0)$ \\
\hline$+U$ - and $g$-values & $94.2(94.1)$ & $89.9(89.7)$ & $87.4(87.2)$ & $86.1(85.9)$ \\
\hline+ Orientation & $94.5(94.4)$ & $89.9(89.9)$ & $87.4(87.3)$ & $86.1(86.0)$ \\
\hline + Window areas & $91.6(91.5)$ & $87.2(87.2)$ & $84.8(84.9)$ & $83.6(83.6)$ \\
\hline \multicolumn{5}{|l|}{$2090 \mathrm{~s}$} \\
\hline Initial with standard technology & $158.2(150.1)$ & $155.5(147.5)$ & $157.7(147.1)$ & $157.0(144.1)$ \\
\hline$+\mathrm{BAT}$ & $100.4(95.2)$ & $97.2(92.2)$ & $98.5(91.3)$ & $95.8(86.7)$ \\
\hline + By-pass of VHR unit & $97.8(93.9)$ & $94.8(90.8)$ & $96.4(90.0)$ & $94.0(85.5)$ \\
\hline + Shading & $93.8(92.3)$ & $90.5(89.1)$ & $90.1(87.4)$ & $86.7(82.6)$ \\
\hline$+U$ - and $g$-values & $94.2(94.1)$ & $90.1(90.0)$ & $87.6(87.1)$ & $82.4(81.1)$ \\
\hline + Orientation & $94.5(94.4)$ & $90.2(90.1)$ & $87.5(87.1)$ & $81.9(80.9)$ \\
\hline+ Window areas & $91.6(91.5)$ & $87.5(87.4)$ & $84.8(84.5)$ & $79.6(78.7)$ \\
\hline
\end{tabular}

implementing each successive design strategy. Total primary energy use for operation of the building decreased by 49 and $42 \%$ under the reference climate of 1996-2005 when the different design strategies are implemented with space heating based on $\mathrm{CHP}$ and $\mathrm{HOB}$, respectively. The corresponding reductions for the future climate scenarios are between 50 and $51 \%$ and $50-54 \%$ for midcentury and end of century periods, respectively, when space heating is based on CHP. For space heating based on $\mathrm{HOB}$, the corresponding reductions are $44-46 \%$ and 44-49\%. Household equipment and technical installations based on BAT give the biggest decrease in primary energy use, while the effectiveness of the other design strategies in reducing primary energy use varies with the climate scenarios. The total primary energy use for the building is averagely about $21-28 \%$ higher when space heating is based on HOB instead of CHP. The use of solar electricity for space cooling under the different climate scenarios gives about $1.5-13 \mathrm{kWh} / \mathrm{m}^{2}(2-13 \%)$ reduction in the total primary energy use for the building, compared to electricity from a stand-alone plant when BAT, Bypass of VHR unit or window shading are implemented. The corresponding reduction when the rest of the measures are implemented is rather small ranging between 0 and $0.1 \mathrm{kWh} / \mathrm{m}^{2}$.

\section{Discussion and conclusions}

The effects of climate change on the space heating and cooling demands of a residential building, designed to the Swedish passive house criteria, have been explored in this study. The analysis shows significant changes in the space heating and cooling demands of the initial building under future climate scenarios. Space heating demand generally decreased while space cooling demand increased considerably. The increases in space cooling demands are more significant for the end of century than mid-century periods, except for the RCP2.6 climate scenario. Space cooling is slightly lower for RCP2.6-2090s compared to RCP2.6-2050s, reflecting underlying assumptions of a peak and decline pathway of radiative forcing based on stringent mitigation goals to achieve substantial GHG emission reductions (van Vuuren et al. 2011). RCP2.6 scenario is reported as the closest to the $2{ }^{\circ} \mathrm{C}$ global temperature target and in line with ambitions of the Paris agreement (UNFCCC United Nations Framework Convention on Climate Change 2015). The changed space cooling demand becomes more significant than the changed space heating demand for the building under all the considered climate scenarios with high risks of 
overheating. This trend is similar to those observed in the performance assessment and analyses of several low energy buildings in different climate contexts (Dodoo and Gustavsson 2016; Rohdin et al. 2014; Tabatabaei Sameni et al. 2015). Currently, cooling demand for residential buildings is low in Sweden and overheating may be controlled by shading and ventilation. However, the risk of overheating may be higher in low energy buildings, especially under warmer climates. Still, high risks of overheating have been reported for several Swedish low energy buildings e.g. passive houses such as has been analysed here (Janson 2010; Persson and Westermark 2012; Rohdin et al. 2014). As the number of low energy buildings is expected to increase across the EU in line with stringent regulations, strategies to minimise both space heating and cooling demands need to be incorporated in the design of such buildings, considering also the impact of climate change.

The space cooling demands were significantly reduced for the building when all the analysed design strategies and measures were implemented under all the climate scenarios and overheating was avoided, except under RCP8.5 for end of century period. Among the considered strategies and measures, household equipment and technical installations based on BAT gave the biggest decrease in total primary energy use under the considered climate scenarios and energy supply systems. This is followed by shading, while the effectiveness of the other strategies varied depending on the climate scenario. The impact of varying the shares of window areas and orientations was found to be minor if all the other design strategies and measures are implemented before. Considering 50-year life time for windows, the choice of windows may be based on optimised $U$ - and $g$-values, considering climate change for the next 50 years. Also, the technical development of more energy efficient household equipment and technical installations will help to reduce future cooling demands if BAT is chosen when these types of equipment and installations have to be replaced.

The primary energy use with space heating based on CHP was notably lower than HOB. The total primary energy use reduced by $8-13 \mathrm{kWh} / \mathrm{m}^{2}$ for the initial building with solar-based electricity for cooling. However, the reduction becomes less significant with the successive implementation of the considered design strategies, reaching $0-1.3 \mathrm{kWh} / \mathrm{m}^{2}$ when all the strategies are implemented. This shows that different design strategies may be prioritised in controlling building cooling demand under climate change. Overall, the total annual primary energy use for operation was reduced between 42 and $54 \%$ after the implemented design strategies and measures under the different climate change scenarios and heat supply systems.

This study considers different design strategies and measures and measures for a typical building typology for the Swedish climate and our conclusions may be valid for other types of buildings within similar climate contexts. Still, specific analysis may be required to evaluate energy benefits of the here considered design strategies and measures as building characteristics could vary in different contexts. Based on cost, design specifications and practical application of the considered strategies, the choice of strategy or order of implementing them may vary. Different buildings may require different sets of strategies to achieve low energy demands under future climate scenarios. This analysis is based on a recently constructed concrete-frame multistorey residential building in southern Sweden. Currently, multi-storey residential buildings form about $51 \%$ of the total dwelling stock in Sweden (Statistiska centralbyrån (SCB) 2018) and this trend is expected to continue in the future. Construction of new multi-storey residential buildings in timber frames is also expected to increase across Sweden with some municipalities such as Växjö already paving the way (Växjö kommun 2017). The composition of the building stock may therefore change in the long term mainly with regard to the type of building frame materials and such dynamics should be considered in the context of this analysis in further studies. The efficiency of energy supply systems and COP of air conditioners as considered here may change over time and this may also influence the effectiveness of the considered strategies and measures. These factors may be explored in further studies.

The variations in the share of window areas and window properties may affect the quantities of materials required for the building frame and, hence, the production primary energy use of buildings. The importance of the choice of frame materials on building production energy use, especially for low energy buildings, has been emphasised in different studies (Cabeza et al. 2013; Takano et al. 2015). This has not been considered here, and further studies may explore the implications of the analysed designed strategies and measures for low energy building systems with different frame materials under future climate scenarios in a life cycle perspective. 
Daylighting benefits may be significant in climates with high solar radiation and daylight availability. However, daylight benefits are limited in the cold season in Nordic countries such as Sweden due to high latitudes and low availability (Dubois and Blomsterberg 2011). The considered variations in the share of window areas meet the recommended limits by the Swedish building code for minimum daylight accessibility. Nevertheless, the potential benefits of daylight in combination with other measures such as electric lighting systems and inner wall reflectance for residential buildings under climate change may be explored in further studies.

Uncertainties linked to climate data and future climate projections may affect the results of our analysis. Future climate projections are based on advanced and high resolution Global Climate Models (GCMs), which continue to improve over time. GCMs are reported as the most advanced tools currently available for simulating the response of the global climate system to increasing GHG concentrations (IPCC Intergovernmental Panel on Climate Change 2013). The analyses in this study are based on the most recent climate scenarios developed by IPCC.

Overall, this study shows the importance of considering different design strategies in minimising the operation energy use and the potential risks of overheating in low-energy residential buildings under climate change.

Acknowledgements The Swedish Meteorological and Hydrological Institute (SMHI) is acknowledged for data on the future climate scenarios.

Funding information This study received financial support from Ronneby municipality (CEFUR), Växjö municipality, Växjöbostäder, Växjö Energi AB, and the Swedish Energy Agency.

\section{Compliance with ethical standards}

Conflict of interest The authors declare that they have no conflict of interest.

Open Access This article is distributed under the terms of the Creative Commons Attribution 4.0 International License (http:// creativecommons.org/licenses/by/4.0/), which permits unrestricted use, distribution, and reproduction in any medium, provided you give appropriate credit to the original author(s) and the source, provide a link to the Creative Commons license, and indicate if changes were made.

\section{References}

Badescu, V., Laaser, N., \& Crutescu, R. (2010). Warm season cooling requirements for passive buildings in Southeastern Europe (Romania). Energy, 35(8), 3284-3300. https://doi. org/10.1016/j.energy.2010.04.013.

Baetens, R., Jelle, B. P., \& Gustavsen, A. (2010). Properties, requirements and possibilities of smart windows for dynamic daylight and solar energy control in buildings: a state-of-theart review. Solar Energy Materials and Solar Cells, 94(2), 87-105. https://doi.org/10.1016/j.solmat.2009.08.021.

BBR Boverkets Byggregler (2015). Boverkets Författningssamling (in English: the Swedish building code), the national Board of Housing Building and planning, (in Swedish). Karlskrona, Sweden.

Belcher, S., Hacker, J., \& Powell, D. (2005). Constructing design weather data for future climates. Building Services Engineering Research and Technology, 26(1), 49-61. https://doi.org/10.1191/0143624405bt112oa.

Berger, T., Amann, C., Formayer, H., Korjenic, A., Pospischal, B., Neururer, C., \& Smutny, R. (2014). Impacts of climate change upon cooling and heating energy demand of office buildings in Vienna, Austria. Energy and Buildings, 80, 517530. https://doi.org/10.1016/j.enbuild.2014.03.084.

Boverket (2013). Optimala kostnader för energieffektivisering underlag enligt Europaparlamentets och rådets direktiv 2010/31/EU om byggnaders energiprestanda [Optimal costs for energy efficiency - basis according to directive 2010/31/ EU of the European Parliament and of the council on the energy performance of buildings].

Brelih, N. (2012). How to improve energy efficiency of fans for air handling units. REHVA Journal, 5-10. Available at https://www.rehva.eu/publications-and-resources/rehvajournal/2012/022012/how-toimprove-energy-efficiency-offans-for-air-handling-units.html. Accessed 4 Feb 2016.

Burke, S., Kronvall, J., Wiktorsson, M., \& Sahlin, P. (2017). Method for probabilistic energy calculations - variable parameters. Energy Procedia, 132, 3-8. https://doi.org/10.1016 /j.egypro.2017.09.622.

Cabeza, L. F., Barreneche, C., Miró, L., Morera, J. M., Bartolí, E., \& Inés Fernández, A. (2013). Low carbon and low embodied energy materials in buildings: a review. Renewable and Sustainable Energy Reviews, 23, 536-542. https://doi. org/10.1016/j.rser.2013.03.017.

Camfil (2014). City pollution. AirMail No. 2. Retrieved from http://www.camfil.se/FileArchive/Brochures/Airmail/ AirMail_2014_2_EN.pdf

CIBSE (2006). Guide A: environmental design, chartered Institute of Building Services Engineers, London.

Cuce, E., \& Riffat, S. B. (2015). A state-of-the-art review on innovative glazing technologies. Renewable and Sustainable Energy Reviews, 41, 695-714. https://doi. org/10.1016/j.rser.2014.08.084.

de Almeida, A., Fonseca, P., Bandeirinha, R., Fernandes, T., Araújo, R., Nunes, U., et al. (2008). Residential monitoring to decrease energy use and carbon emissions in Europe (REMODECE). Intelligent Energy Europe (https://ec. europa.eu/energy/intelligent/projects). Accessed $25 \mathrm{Feb}$ 2016. 
Dodoo, A., \& Gustavsson, L. (2016). Energy use and overheating risk of Swedish multi-storey residential buildings under different climate scenarios. Energy, 97, 534-548. https://doi. org/10.1016/j.energy.2015.12.086.

Dubois, M.-C., \& Blomsterberg, Å. (2011). Energy saving potential and strategies for electric lighting in future north European, low energy office buildings: a literature review. Energy and Buildings, 43(10), 2572-2582. https://doi. org/10.1016/j.enbuild.2011.07.001.

Eurostat (2016). Energy, transport and environment indicators. Eurostat, 2016. Available at: http://epp.eurostat.ec.europa.eu.

FEBY 12 (2012). Kravspecifikation för nollenergihus passivhus och minienergihus Bostäder. Available at www. passivhuscentrum.se/sites/default/files/kravspecifikation (In Swedish).

Gaterell, M. R., \& McEvoy, M. E. (2005). The impact of climate change uncertainties on the performance of energy efficiency measures applied to dwellings. Energy and Buildings, 37(9), 982-995. https://doi.org/10.1016/j.enbuild.2004.12.015.

Gustavsson, L., \& Karlsson, Å. (2006). CO2 mitigation: on methods and parameters forcomparison of fossil fuel and biofuel systems. Mitigation and Adaptation Strategies for Global Change, 11, 935-959.

Hammarberg, E., \& Roos, A. (2003). Anti-reflection treatment of low-emitting glazings for energy efficient windows with high visible transmittance. Thin Solid Films, 442(1-2), 222-226. https://doi.org/10.1016/S0040-6090(03)00986-6.

Holmes, M. J., \& Hacker, J. N. (2007). Climate change, thermal comfort and energy: meeting the design challenges of the 21st century. Energy and Buildings, 39(7), 802-814. https://doi.org/10.1016/j.enbuild.2007.02.009.

IEA International Energy Agency (2012). $\mathrm{CO}_{2}$ emissions from fuel combustion. Beyond 2020 online database. Paris, 138 pp. Available at: http://data.iea.org. Accessed 11 Jan 2017.

IEA International Energy Agency (2015). $\mathrm{CO}_{2}$ emissions from fuel combustion. Highlights. Available at: http://data.iea.org. Accessed 11 Jan 2017.

IPCC Intergovermental Panel on Climate Change. (2013). Climate Change 2013: The Physical Science Basis. Contribution of Working Group I to the Fifth Assessment Report of the Intergovernmental Panel on Climate Change [Stocker, T.F., D. Qin, G.-K. Plattner, M. Tignor, S.K. Allen, J. Boschung, A. Nauels, Y. Xia, V. Bex and P.M. Midgley (eds.)]. Cambridge University Press, Cambridge, United Kingdom and New York, NY, USA, $1535 \mathrm{pp}$.

IPCC Intergovernmental Panel on Climate Change (2013). What is a GCM? Available at http://www.ipcc-data. org/guidelines/pages/gcm_guide.html. Accessed 12 Dec 2016.

IPCC Intergovernmental Panel on Climate Change (2014a). Climate Change 2014: Impacts, Adaptation, and Vulnerability. Part A: Global and Sectoral Aspects. Contribution of Working Group II to the Fifth Assessment Report of the Intergovernmental Panel on Climate Change [Field, C.B., V.R. Barros, D.J. Dokken, K.J. Mach, M.D. Mastrandrea, T.E. Bilir, M. Chatterjee, K.L. Ebi, Y.O. Estrada, R.C. Genova, B. Girma, E.S. Kissel, A.N. Levy, S. MacCracken, P.R. Mastrandrea, and L.L. White (eds.)]. Cambridge University Press, Cambridge, United Kingdom and New York, NY, USA, $1132 \mathrm{pp}$.
IPCC Intergovernmental Panel on Climate Change. (2014b). Climate Change 2014: Mitigation of Climate Change. Contribution of Working Group III to the Fifth Assessment Report of the Intergovernmental Panel on Climate Change [Edenhofer, O., R. Pichs-Madruga, Y. Sokona, E. Farahani, S. Kadner, K. Seyboth, A. Adler, I. Baum, S. Brunner, P. Eickemeier, B. Kriemann, J. Savolainen, S. Schlömer, C. von Stechow, T. Zwickel and J.C. Minx (eds.)]. Cambridge University Press, Cambridge, United Kingdom and New York, NY, USA.

IPCC Intergovernmental Panel on Climate Change (2014c). Climate Change 2014: Synthesis Report. Contribution of Working Groups I, II and III to the Fifth Assessment Report of the Intergovernmental Panel on Climate Change [Core Writing Team, R.K. Pachauri and L.A. Meyer (eds.)]. IPCC, Geneva, Switzerland, $151 \mathrm{pp}$.

Isover. (2016). IsoDim. Heat loss calculation. Available at: www. programbyggerne.no/IsodimSE. Accessed 16 Jan 2017.

Janson, U. (2010). Passive houses in Sweden - From design to evaluation of four demonstration projects. (Doctoral Thesis), Lund University, Lund, Sweden. (Report EBD-T-10/12).

Karimpour, M., Belusko, M., Xing, K., Boland, J., \& Bruno, F. (2015). Impact of climate change on the design of energy efficient residential building envelopes. Energy and Buildings, 87, 142-154. https://doi.org/10.1016/j. enbuild.2014.10.064.

Liu, L., Rohdin, P., \& Moshfegh, B. (2015). Evaluating indoor environment of a retrofitted multi-family building with improved energy performance in Sweden. Energy and Buildings, 102, 32-44. https://doi.org/10.1016/j. enbuild.2015.05.021.

Lundström, L., \& Wallin, F. (2016). Heat demand profiles of energy conservation measures in buildings and their impact on a district heating system. Applied Energy, 161, 290-299. https://doi.org/10.1016/j.apenergy.2015.10.024.

Minne, E., Wingrove, K., \& Crittenden, J. C. (2015). Influence of climate on the environmental and economic life cycle assessments of window options in the United States. Energy and Buildings, 102, 293-306. https://doi.org/10.1016/j. enbuild.2015.05.039.

Mlakar, J., \& Štrancar, J. (2011). Overheating in residential passive house: solution strategies revealed and confirmed through data analysis and simulations. Energy and Buildings, 43(6), 1443-1451. https://doi.org/10.1016/j.enbuild.2011.02.008.

Mora, C., Frazier, A. G., Longman, R. J., Dacks, R. S., Walton, M. M., Tong, E. J., et al. (2013). The projected timing of climate departure from recent variability. Nature, 502, 183-187.

Noris, F., Musall, E., Salom, J., Berggren, B., Jensen, S. Ø., Lindberg, K., \& Sartori, I. (2014). Implications of weighting factors on technology preference in net zero energy buildings. Energy and Buildings, 82, 250-262. https://doi. org/10.1016/j.enbuild.2014.07.004.

Persson, J., \& Westermark, M. (2012). Phase change material cool storage for a Swedish passive house. Energy and Buildings, 54, 490-495. https://doi.org/10.1016/j.enbuild.2012.05.012.

Remund, J., Muller, S. C., Schilter, C., Rihm, B. (2010). The use of Meteonorm weather generator for climate change studies. In: EMS annual meeting: EMS2010-417.

Rohdin, P., Molin, A., \& Moshfegh, B. (2014). Experiences from nine passive houses in Sweden - Indoor thermal environment 
and energy use. Building and Environment, 71, 176-185. https://doi.org/10.1016/j.buildenv.2013.09.017.

Rubio-Bellido, C., Pérez-Fargallo, A., \& Pulido-Arcas, J. A. (2016). Optimization of annual energy demand in office buildings under the influence of climate change in Chile. Energy, 114, 569-585. https://doi.org/10.1016/j. energy.2016.08.021.

Saheb, Y., Bódis, K., Szabó, S., Ossenbrink, H., \& Panev, S. (2015). Energy Renovation: the Trump Card for the New Start for Europe (report EUR $26888 \mathrm{EN}$ ). Retrieved from JRC science and policy reports. Web accessed at http://iet.jrc. ec.europa.eu/energyefficiency/system/tdf/eur26888 buildingreport_online.pdf?file $=1 \&$ type $=$ node $\& i d=9069$ on October 3, $201 \overline{5}$.

Sanford, T., Frumhoff, P. C., Luers, A., \& Gulledge, J. (2014). The climate policy narrative for a dangerously warming world. Nature Clim. Change, 4(3), 164-166. https://doi.org/10.1038 /nclimate2148.

Siggelsten, S. (2014). Reallocation of heating costs due to heat transfer between adjacent apartments. Energy and Buildings, 75, 256-263. https://doi.org/10.1016/j.enbuild.2014.02.022.

Smeds, J., \& Wall, M. (2007). Enhanced energy conservation in houses through high performance design. Energy and Buildings, 39(3), 273-278. https://doi.org/10.1016/j. enbuild.2006.07.003.

SMHI (Swedish Meteorological and Hydrological Institute) (2013). Klimatscenarier (In English: Climate Scenarios). Available at http://www.smhi.se/klimat/framtidensklimat $/$ klimatscenarier\#area $=\mathrm{swe} \& \mathrm{dnr}=99 \& \mathrm{sc}=\mathrm{rcp} 85$ \&seas=ar\&var=t. Accessed 25 May 2017.

SMHI Swedish Meteorological and Hydrological Institute (2011). Rossby Centre regional atmospheric model, RCA4. Available at http://www.smhi.se/en/research/researchdepartments/climate-research-rossby-centre2-552/rossbycentre-regional-atmospheric-model-rca4-1.16562. Accessed 12 Jan 2017.

SMHI Swedish Meteorological and Hydrological Institute (2015). Climate indicators - temperature. Available at http://www. smhi.se/en/climate/climate-indicators/climate-indicatorstemperature-1.91472. Accessed 12 Jan 2017.

Statistiska centralbyrån (SCB) (2018). Statistics Sweden. Dwelling stock 2017-12-31. Accessed 4 June 2018 at http://www.scb.se/en/finding-statistics/statistics-by-subjectarea/housing-construction-and-building/housingconstruction-and-conversion/dwelling-stock/.

StruSoft (2012). Sweden. http://www.strusoft.com/products/vipenergy Patent No.: StruSoft AB.

SVEBY (2013). Brukarindata bostader version 1.1. Accessed at http://www.sveby.org/hur-anvander-jag-sveby/berakning/. 29th June, 2015.
Swedish Energy Agency (2010). FTX-aggregat hus med $130 \mathrm{~m} 2$ boyta. Available at https://www.energimyndigheten. se/Hushall/Testerresultat/Testresultat/FTX-aggregat-husmed-130-m-boyta/?tab=1. Accessed 9 Jan 2017.

Swedish Energy Agency (2015a). Energy-efficient taps and shower heads. http://www. energimyndigheten. se/en/sustainability/households/other-energy-consumptionin-your-home/water-and-water-heater/. Accessed $25 \mathrm{Feb}$ 2016.

Swedish Energy Agency (2015b). Energy in Sweden 2015. Available at www.energimyndigheten.se, Swedish Energy Agency. Accessed 12 Jan 2017.

Swedish Energy Agency (2016). Energy in Sweden - Facts and Figures 2016. Available at: http://www.energimyndigheten. se/en/news/2016/energy-in-sweden — facts-and-figures2016-available-now/. Accessed 10 Jan 2017.

Tabatabaei Sameni, S. M., Gaterell, M., Montazami, A., \& Ahmed, A. (2015). Overheating investigation in UK social housing flats built to the Passivhaus standard. Building and Environment, 92, 222-235. https://doi.org/10.1016/j. buildenv.2015.03.030.

Takano, A., Pal, S. K., Kuittinen, M., Alanne, K., Hughes, M., \& Winter, S. (2015). The effect of material selection on life cycle energy balance: a case study on a hypothetical building model in Finland. Building and Environment, 89, 192-202. https://doi.org/10.1016/j.buildenv.2015.03.001.

Truong, N. L., Dodoo, A., \& Gustavsson, L. (2014). Effects of heat and electricity saving measures in district-heated multistory residential buildings. Applied Energy, 118, 57-67. https://doi.org/10.1016/j.apenergy.2013.12.009.

UNFCCC United Nations Framework Convention on Climate Change (2015). Adoption of the Paris agreement, conference of the parties on its twenty-first session.

van Vuuren, D. P., Edmonds, J., Kainuma, M., Riahi, K., Thomson, A., Hibbard, K., Hurtt, G. C., Kram, T., Krey, V., Lamarque, J. F., Masui, T., Meinshausen, M., Nakicenovic, N., Smith, S. J., \& Rose, S. K. (2011). The representative concentration pathways: an overview. Climatic Change, 109(1), 5-31. https://doi.org/10.1007/s10584-011-0148-z.

Växjö kommun (2017). Träbyggnadsprojekt Torparängen. Available at https://www.vaxjo.se/sidor/trafik-ochstadsplanering/stadsutveckling/torparangen/trabyggnadsprojekttorparangen.html. Accessed 27 Jan 2017.

Wang, H., \& Chen, Q. (2014). Impact of climate change heating and cooling energy use in buildings in the United States. Energy and Buildings, 82, 428-436. https://doi.org/10.1016 /j.enbuild.2014.07.034. 